\title{
EXPERIMENTAL STUDIES OF THE PATHOGENESIS OF PSEUDOMONAS AERUGINOSA INFECTION: EVIDENCE FOR THE IN-VIVO PRODUCTION OF A LETHAL TOXIN
}

\author{
D. D. STIERITZ* AND I. A. Holder \\ Departments of Microbiology and Surgery, * University of Cincinnati College of Medicine, \\ and \\ The Shriners Burns Institute, 202 Goodman Street, Cincinnati, Ohio 45219, USA
}

\section{Plate V}

IN a previous report (Stieritz and Holder, 1975) we described an experimental burned-mouse model that was particularly suitable for investigating the pathogenesis of Pseudomonas aeruginosa infection; early events in the establishment of the infection within the burned host were studied and growth of the organism in vivo was examined by quantitative bacteriological procedures. The results suggested that a lethal toxin was produced at the site of infection in the burned skin, and histological studies supported this hypothesis.

Earlier investigators suggested that a lethal, diffusible toxin is produced by $P$. aeruginosa in the wounds of burned patients (Moncrief and Teplitz, 1964; Alexander, 1971). Furthermore, the degree of toxaemia was found to be related to the concentration of organisms in the burned tissues (Alexander, 1971).

Our earlier studies suggested that the mouse model might be useful in the study of infection of burns, and this communication reports further experimental evidence that $P$. aeruginosa growing in burned tissues produces a lethal toxin.

\section{MATERIALS AND METHODS}

Animals and procedures. All experiments were performed with female $\mathrm{CF}_{1}$ mice (Carworth Farms) weighing 22-24 g. Animals were housed in wire cages and given food and water ad libitum.

The procedure used in producing burns has previously been described (Holder and Jogan, 1971). Anaesthetised mice were given a 10-s burn with an ethanol flame on the shaved back involving approximately $30 \%$ of the total body surface. Immediately thereafter approximately 100 organisms in $0.5 \mathrm{ml}$ of physiological saline (PS) were injected subcutaneously in the burned area. Burned but uninfected control animals received $0.5 \mathrm{ml}$ of sterile PS instead of bacterial suspension.

$P$. aeruginosa. Throughout these studies a single strain, originally isolated from the intestinal tract of a normal $\mathrm{CF}_{1}$ mouse (Stieritz and Holder, 1975), was used.

Counts of $P$. aeruginosa in tissues and organs. Counts in the burned skin, livers and spleens of infected animals were determined, either immediately post mortem or at the time stated, by the method of Saymen et al. (1972). Results are expressed as the $\log _{10}$ of the count per gram (wet weight) of tissue.

Received 18 Apr. 1977; revised version accepted 9 Aug. 1977.

* Present address: Department of Microbiology and Immunology, Hahnemann Medical College and Hospital, Philadelphia, Pennsylvania 19102, USA.

Reprint requests to I.A.H.

J. MED. MICROBIOL.-VOL. 11 (1978) 
Mouse skin extracts. Extract of infected burned skin (ISE) and of uninfected burned skin (BSE) were prepared from tissue homogenates, produced as described by Saymen $e t$ al. (1972) except that $0.01 \mathrm{M}$ phosphate buffered saline (PBS) $p \mathrm{H} 7.5$ was used. Tissue in PBS $\left(c .0 .15-0.2 \mathrm{~g}\right.$ per ml) was homogenised and centrifuged at $17500 \mathrm{~g}$ for $60 \mathrm{~min}$. at $5^{\circ} \mathrm{C}$. The clear supernate was removed and the pellet and floating lipid layer were discarded. The supernate was filtered through a $0 \cdot 45-\mu \mathrm{m}$ Millipore filter and stored in sterile containers at $-70^{\circ} \mathrm{C}$ until used. Each millilitre of extract contained approximately $10 \mathrm{mg}$ of protein.

Antibiotic therapy of infected animals. Burned-and-infected mice were treated with gentamicin after various intervals so that the effect of the treatment on the numbers of $P$. aeruginosa in burned skin, liver and spleen could be measured by the quantitative methods already described.

Each animal received $0.1 \mathrm{ml}$ of gentamicin solution intraperitoneally and a similar volume subcutaneously in the infected burned area, the total dose per kilogram bodyweight being $100 \mathrm{mg}$. Burned but uninfected control animals showed no signs of intoxication when given double this dose of gentamicin.

Control experiments showed that little or no reduction of bacterial counts was produced in our experiments by gentamcin carried over into the tissue homogenates.

Preparation of rabbit antisera against burned skin extracts. Groups of four rabbits (female, New Zealand white) weighing 2-2.5 kg (Sweetwater Farms, Inc.) were immunised by subcutaneous and intramuscular injections at several sites of $2 \mathrm{ml}$ of either ISE or BSE emulsified in $2 \mathrm{ml}$ of Freund's complete adjuvant.

Two weeks after primary immunisation, small blood samples were taken from all rabbits. Two days later, if ISE or BSE antibodies had proved to be demonstrable, the rabbits were bled again and the sera in each group were pooled, filter-sterilised and stored in aliquots at $-70^{\circ} \mathrm{C}$. These sera were used for subsequent absorption of the ISE. Two months after the primary injection, the response of each rabbit was boosted with an intramuscular injection of $2 \mathrm{ml}$ of the original immunogen (ISE or BSE) without adjuvant. However, before this injection, the ISE was absorbed with BSE antiserum and concentrated two-fold in an Amicon B-15 micrococentrator (Amicon Corp.).

Approximately 3 weeks after the second injection, all rabbits were bled and the sera in each group were pooled and treated as described above.

Absorption of rabbit sera. Rabbit antisera prepared against BSE (BSAS) and against ISE (ISAS) were each absorbed with BSE as follows: $0.1 \mathrm{ml}$ of BSE was added to $2 \mathrm{ml}$ of antiserum in a $3 \mathrm{ml}$ centrifuge tube and incubated at $37^{\circ} \mathrm{C}$ in a shaking waterbath for $60 \mathrm{~min}$. The mixtures were then centrifuged at $2000 \mathrm{~g}$ for $15 \mathrm{~min}$. at $5^{\circ} \mathrm{C}$. The supernate was transferred to another tube and again absorbed with BSE. The procedure was repeated until no visible precipitate was detectable after incubation and centrifugation. The absorbed sera were used in gel immunodiffusion studies.

Gel precipitation studies were carried out with the absorbed antisera and the original immunogens by the method described by Campbell $e t$ al. (1963).

Protection studies with gentamicin and antiserum. Groups of burned-and-infected mice were treated at various intervals with antiserum alone or with antiserum and gentamicin. Treatment with rabbit antiserum consisted of an intraperitoneal injection of $0.5 \mathrm{ml}$. The numbers of survivors in the various groups were recorded at 0.5 -h intervals, and bacterial counts after antiserum treatment were performed as previously described.

Mouse immunisation with heat-killed P. aeruginosa. P. aeruginosa was grown in Brain Heart Infusion Broth on a rotary shaker at $35^{\circ} \mathrm{C}$ for $20 \mathrm{~h}$. The viable count was determined by plating serial dilutions and the remaining suspension was killed by heating for $1 \mathrm{~h}$ at $80^{\circ} \mathrm{C}$ and checked for sterility. After the viable count became known, the suspension was adjusted to a concentration of $10^{10}$ cells per $\mathrm{ml}$. A group of 15 unburned mice received an intravenous injection of $10^{9}$ heat-killed $P$. aeruginosa. Fourteen days later the animals were killed and their serum was collected and stored.

Passive protection studies. Twenty-two hours after burning and infection, two groups of six or seven mice were given an intraperitoneal injection of $0.5 \mathrm{ml}$ of mouse serum; one group received antiserum collected from the mice that had previously received an injection 
of heat-killed cells of $P$. aeruginosa and the other group received normal mouse serum. Bacterial counts were performed on samples of the burned skin, liver and spleen $4.5 \mathrm{~h}$ after treatment.

Statistical analysis. The time to death and the viable counts in the burned skin, liver and spleen after various treatments were expressed as the mean \pm SEM. Differences between treatment groups were tested by the Student's $t$ test and were considered significant when $\mathrm{P}$ was less than 0.05 .

\section{RESULTS}

We showed earlier (Stieritz and Holder, 1975) that mice burned and immediately given $P$. aeruginosa by subcutaneous inoculation in the burned tissues succumbed to rapidly fatal infection. The fact that the animals appeared moribund $20 \mathrm{~h}$ after infection when organisms were only just detectable in the major organs, and the absence of inflammatory lesions in these organs, suggested the possibility of a generalised toxaemia originating in the heavily infected burned-skin tissues. However, intravenous injections of $0.1 \mathrm{ml}$ of ISE or the sera from burned and infected mice into normal or burned mice failed to demonstrate a lethal effect. In the present study we immunised a group of rabbits with ISE to produce antiserum (ISAS) against a putative toxin. AntiBSE serum (BSAS) produced in a second group of rabbits served as control serum.

\section{Gel precipitation studies}

The tests were performed with the burned skin extracts and rabbit antisera. The resulting immunodiffusion pattern is shown in fig. 1. At least two precipitin bands were identified between ISE and ISAS absorbed with BSE. These same bands were demonstrable with the unabsorbed ISAS. The fact that they were not absorbed with BSE indicated the presence of antibodies directed against antigens that occurred in ISE but not in BSE. The patterns developed only after repeated filling of the reaction wells and this indicated very low antigen concentrations in the ISE preparation. It may explain why our earlier studies failed to demonstrate that this preparation possessed lethal properties. The heavier precipitin bands seen with BSAS indicated reactions of identity that resulted from the incomplete absorption of common skin antigens.

\section{Treatment with ISAS and gentamicin}

If the antibodies peculiar to ISAS were in fact antitoxic, treatment with ISAS might protect infected mice. To test this hypothesis, $0.5 \mathrm{ml}$ of antiserum was injected intraperitoneally into mice at intervals late in the course of infection. Fig. 2 shows the results of ISAS or BSAS treatment $22 \mathrm{~h}$ after infection. ISAS treatment did not result in greatly prolonged survival, but a comparison of the mean time to death (MTD) between groups of animals treated with ISAS and BSAS at various times after infection (fig. 3) shows that there was a significant $(P<0.05)$ increase in the MTD of the ISAS-treated group as compared with that of the BSAS-treated group.

The results presented in the table show that treatment with gentamicin significantly $(\mathrm{P}<0.05)$ reduced the numbers of $P$. aeruginosa. Animals were then treated with both gentamicin and antiserum to determine whether the 


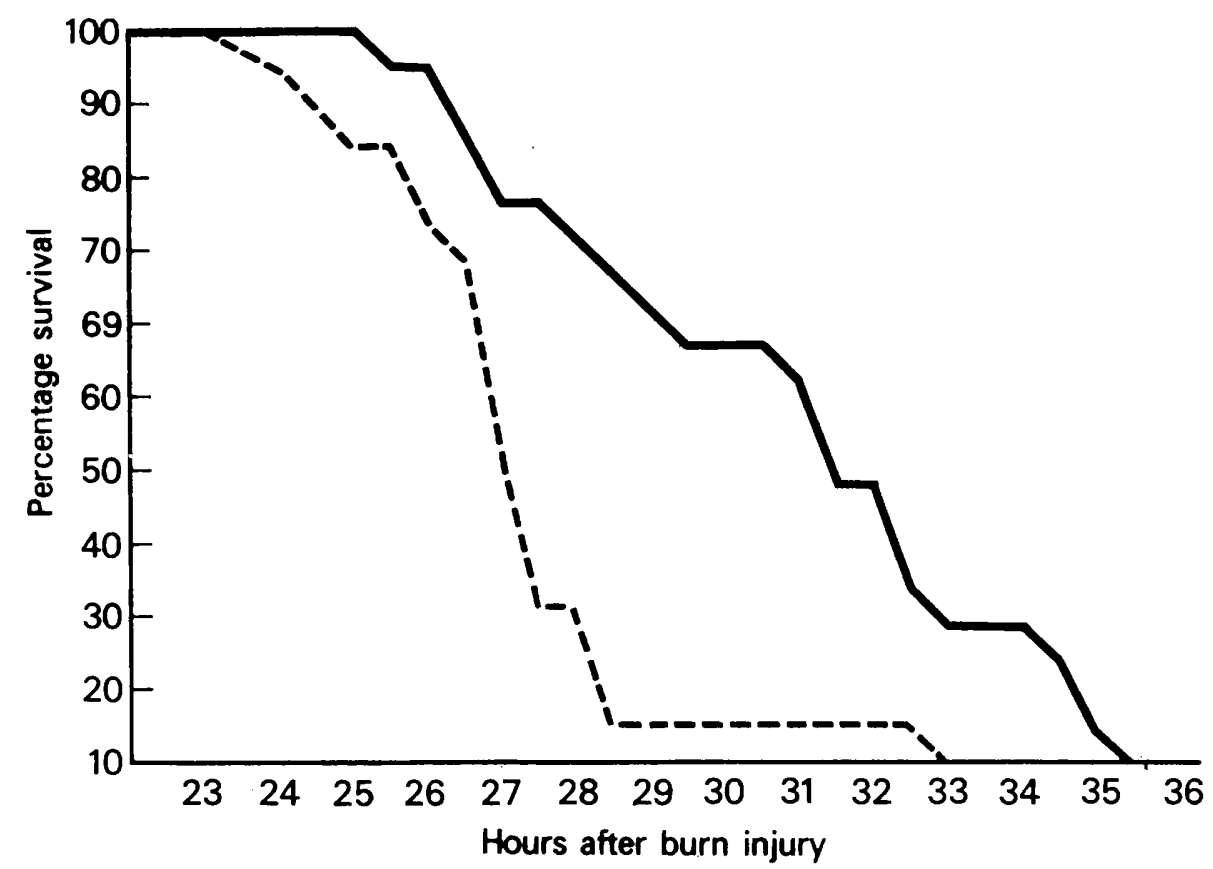

Fig. 2.-Effect of treatment of mice with rabbit antiserum against ISE (ISAS) or against BSE (BSAS) $22 \mathrm{~h}$ after burn injury and infection with $P$. aeruginosa. The ISAS-treated group $(-)$ and BSAS-treated group (-...-) contained 21 and 19 mice respectively.

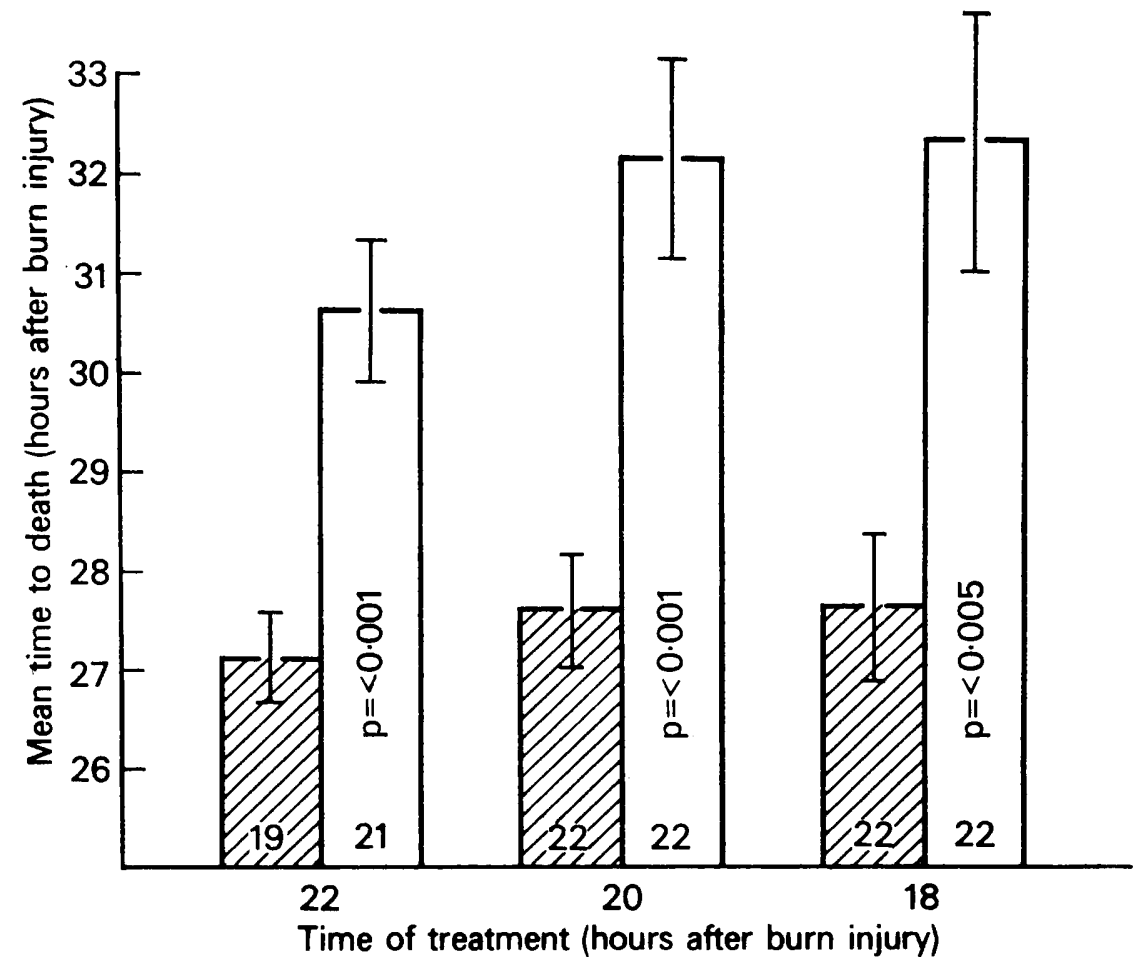

FIG. 3.-Mean time to death of burned-and-infected mice treated with rabbit antiserum ISAS ( $\square$ ) or BSAS (河). The numbers of mice in each treatment group ranged from 19 to 22 , as shown. 


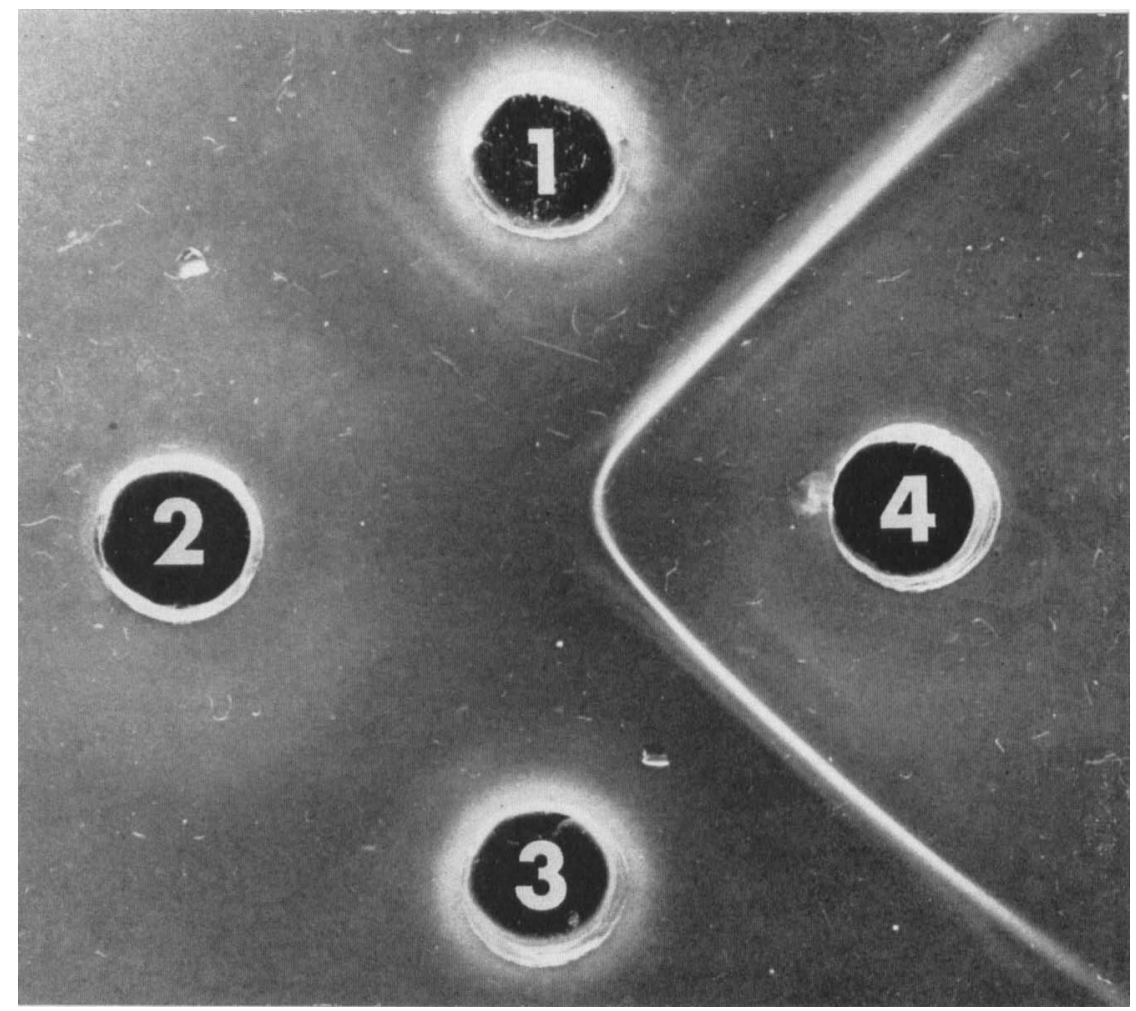

FIG. 1.-Gel precipitation test with mouse skin extracts and absorbed rabbit antisera. (1) Extract of the skin of burned-and-infected (P. aeruginosa) mice; (2) rabbit serum prepared against ISE and absorbed with an extract (BSE) of burned but uninfected mouse skin; (3) BSE; (4) rabbit serum prepared against BSE (BSAS) and absorbed with BSE. 
combination of antibiotic and ISAS would favourably affect survival or MTD. The results are shown in fig. 4. Neither gentamicin alone nor gentamicin in combination with BSAS greatly affected survival, but $40 \%$ of animals treated with a combination of gentamicin and ISAS were still alive $96 \mathrm{~h}$ after infection.

Bacterial counts of burned skin, liver and spleen were determined $4.5 \mathrm{~h}$ after treatment with ISAS or BSAS to examine the possibility that ISAS contained antibodies to somatic antigens of $P$. aeruginosa; such antibodies might assist in reducing the number of infecting organisms and might help to explain the greater protection produced by the combination of gentamicin and

TABLE

The effect of gentamicin treatment on mice with $P$. aeruginosa-infected burns

\begin{tabular}{|c|c|c|c|c|c|}
\hline \multirow{2}{*}{$\begin{array}{c}\text { Time }(\mathrm{h}) \\
\text { between } \\
\text { infection and } \\
\text { treatment* }\end{array}$} & \multicolumn{3}{|c|}{$\log _{10}$ number of organisms $\uparrow$ per $g$ of } & \multirow{2}{*}{$\begin{array}{l}\text { Mean time } \\
\text { to death (h) }\end{array}$} & \multirow{2}{*}{$\begin{array}{c}\text { Number of survivors at } \\
48 \mathrm{~h} \text { out of number } \\
\text { tested (and percentage } \\
\text { survival) }\end{array}$} \\
\hline & $\begin{array}{c}\text { burned } \\
\text { skin }\end{array}$ & liver & spleen & & \\
\hline Controls & $8.89(6)$ & $6.62(11)$ & $6 \cdot 84(11)$ & $26 \cdot 4$ & $0 / 16(0)$ \\
\hline $\begin{array}{l}24 \\
22 \\
20 \\
18\end{array}$ & $\begin{array}{l}4 \cdot 67(6) \\
4 \cdot 32(6) \\
3 \cdot 74(2) \\
\quad \ldots\end{array}$ & $\begin{array}{c}4 \cdot 72(6) \\
4 \cdot 21(6) \\
3 \cdot 02(2) \\
\quad \ldots\end{array}$ & $\begin{array}{c}4 \cdot 77(6) \\
4 \cdot 06(6) \\
3 \cdot 10(2) \\
\ldots\end{array}$ & $\begin{array}{c}27 \cdot 6 \\
28 \cdot 4 \\
31 \cdot 9 \\
\cdots\end{array}$ & $\begin{array}{c}0 / 12(0) \\
1 / 16(6) \\
11 / 18(61) \\
6 / 6(100)\end{array}$ \\
\hline
\end{tabular}

* Gentamicin $50 \mathrm{mg}$ per $\mathrm{kg}$ given intraperitoneally and subcutaneously in equal doses at the stated time (see Methods).

$\dagger \log _{10}$ number of $P$. aeruginosa per $\mathbf{g}$ of tissue at death, with number of test animals given in brackets.

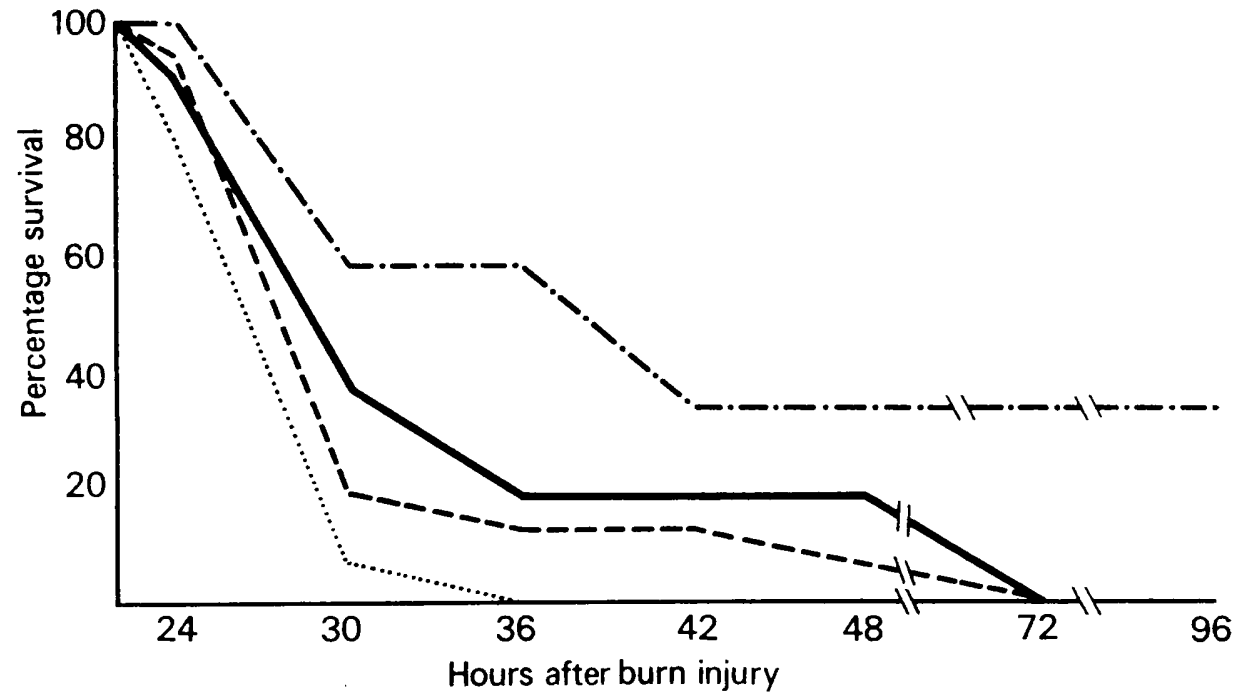

Fig. 4. - Effect of treatment of mice $22 \mathrm{~h}$ after burn injury and infection. - - - - - Gentamicin +ISAS (16 mice); $-=$ gentamicin +BSAS $(11$ mice);..$-=$ gentamicin (16 mice); $\ldots \ldots=$ no treatment $(30$ mice). 
ISAS than by gentamicin treatment alone. The data in fig. 5 show that despite the increase in the MTD brought about by the ISAS, there was no significant difference between the numbers of organisms in the tissues of animals receiving ISAS or BSAS treatment. In fact, the mean counts of organisms found in the ISAS-treated group were similar to or higher than the counts seen previously in untreated control animals at the time of death (table).

\section{Treatment with mouse antiserum}

Similar experiments were performed with mouse antiserum prepared against heat-killed $P$. aeruginosa (EAS). The results (fig. 6) indicate that the livers of EAS-treated mice contained significantly less $(P<0.05)$ organisms than did those of mice treated with normal mouse serum.

\section{Discussion}

Liu (1966) described a toxin, produced in rabbit skin after subcutaneous injection of viable $P$. aeruginosa, that was lethal to mice when given in large amounts. More recent reports (Pavlovskis, 1972; Pavlovskis and Gordon 1972; Liu, 1973; Liu and Hsieh, 1973; Liu, Yoshii and Hsieh, 1973; Callahan 1974; Pavlovskis and Shackelford, 1974) described the purification of an " exotoxin " produced in vitro by $\boldsymbol{P}$. aeruginosa that was lethal for laboratory animals. That such an exotoxin is produced in vivo and that it accounts for the pathology seen in clinical infections remains to be shown.

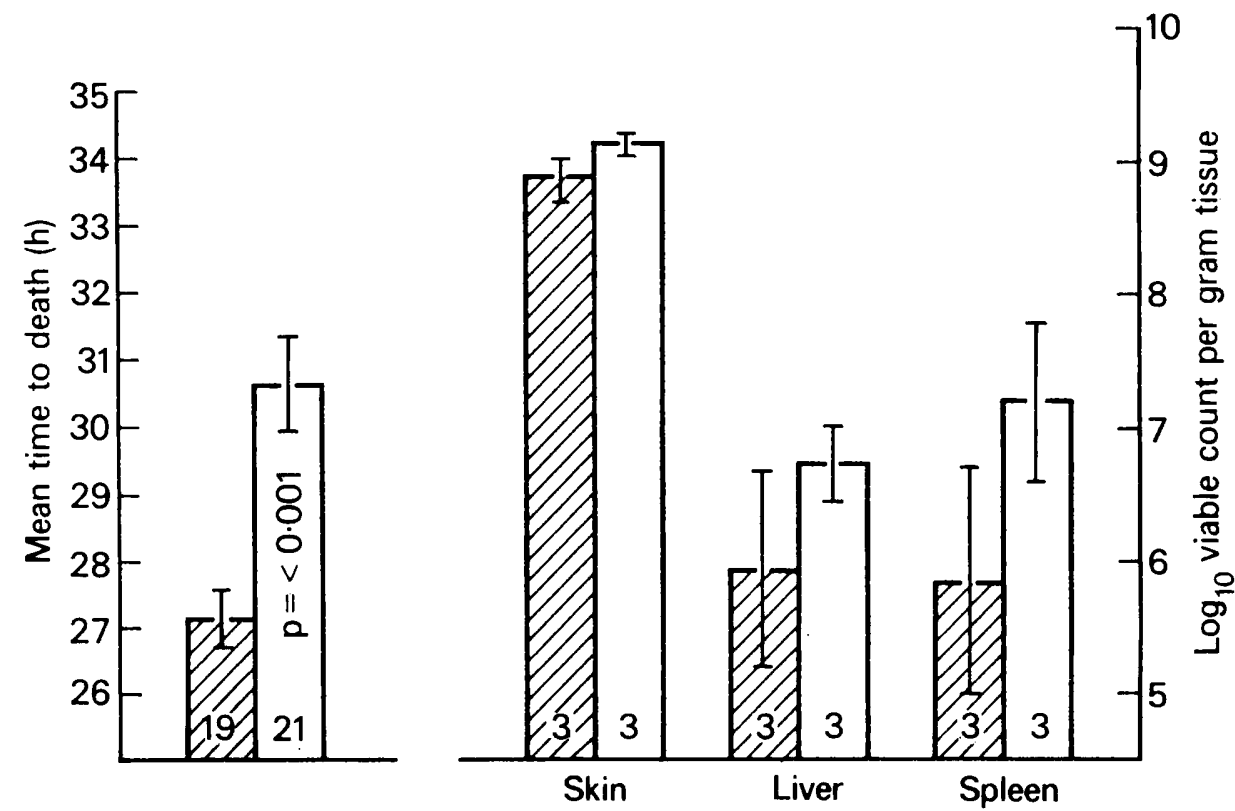

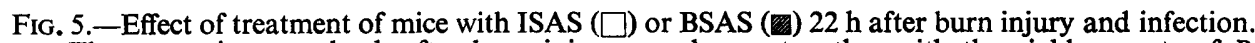
The mean times to death after burn injury are shown, together with the viable counts of $\boldsymbol{P}$. aeruginosa in burned skin, liver and spleen $4.5 \mathrm{~h}$ after treatment. The numbers of mice per treatment groups or per sample are shown. 


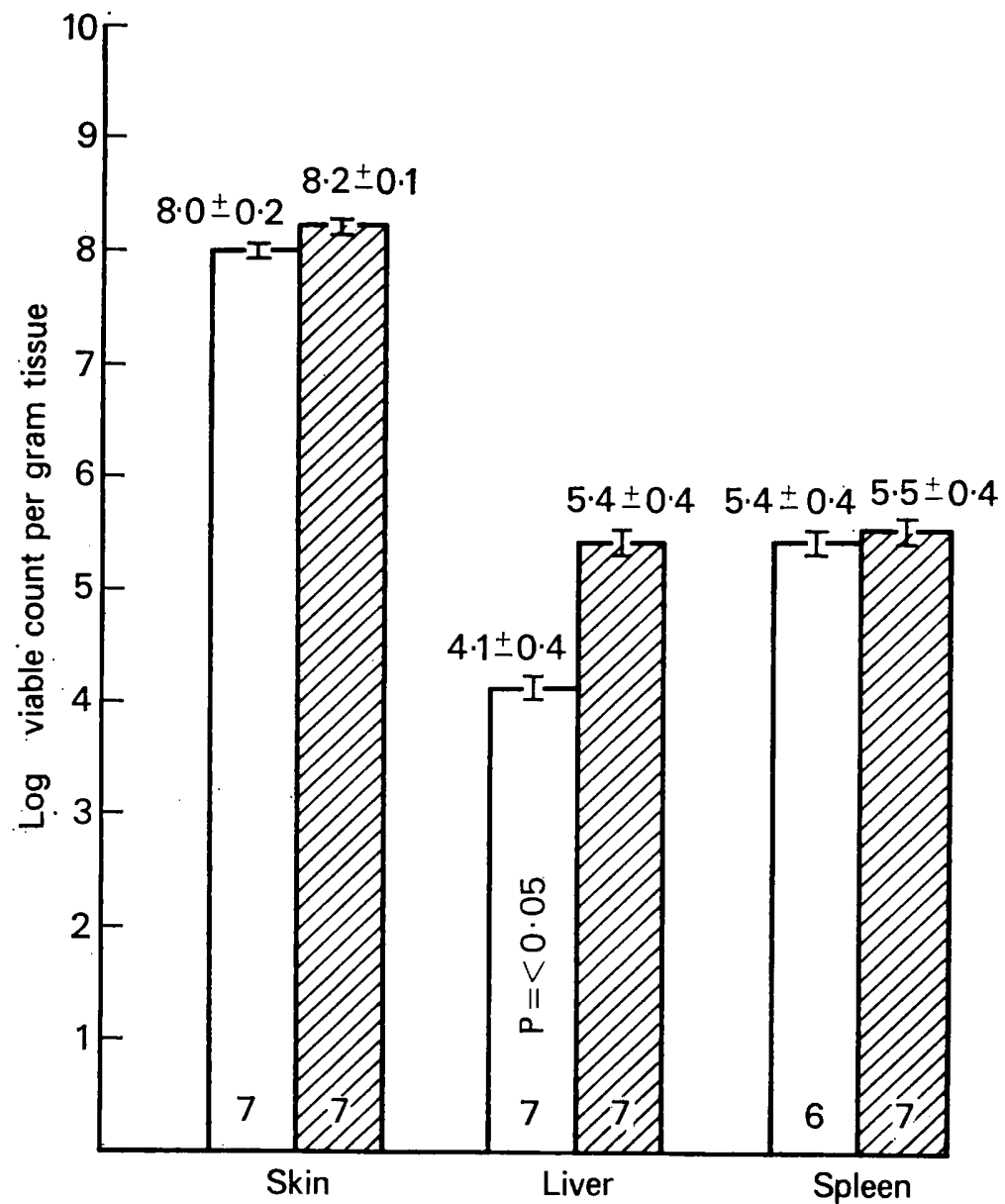

FIG. 6.-Effect of treatment of mice with mouse antiserum ( $\square$ ) against heat-killed $P$. aeruginosa or with normal mouse serum (國) $22 \mathrm{~h}$ after burn injury and infection. The viable counts of $P$. aeruginosa in burned skin, liver and spleen $4.5 \mathrm{~h}$ after treatment, and the numbers of mice examined (six or seven) are shown.

A previous report from this laboratory (Stieritz and Holder, 1975) described the experimental animal model used in these studies and suggested that its use was relevant to the problems posed by the infection of burns with $P$. aeruginosa. It was shown that the presence of burns rendered mice susceptible to a rapidly fatal infection after the injection of only 10 viable $P$. aeruginosa cells. Mice with burns did not show the same susceptibility to other micro-organisms tested. The purpose of developing the model was to examine the possible production in vivo of lethal factors. The infecting organisms were generally restricted to the inoculated burned tissues and they were not seen in the major organs and blood until after the animals appeared moribund and this suggested that an extracellular component was involved.

Treatment of burned-and-infected animals with gentamicin, late in the course of the infection, significantly reduced the numbers of infecting $P$. aeruginosa and resulted in an increased MTD but there was no increase in 
long-term survival. This also suggested the presence of an extracellular toxin. A study by Bartell, Orr and Garcia (1968) showed similar results in mice treated with a specific virulent-phage preparation; this significantly reduced the numbers of infecting organisms late in the course of infection without increasing survival. These workers suggested that the lethal process had already been initiated and was independent of continued microbial growth in the host. Our results, in addition, showed that the infecting organisms at the time of gentamicin treatment were generally restricted to burned skin tissues. As gentamicin-treated animals survived slightly longer than untreated controls the treatment may have prevented or retarded the further accumulation of a toxic product.

In the present study, results of the immunodiffusion tests showed that the infected skin preparations gave precipitation bands that were not given by preparations of uninfected skin. If these precipitation bands represented antibodies directed against a toxin of $P$. aeruginosa in the ISE, serum containing such antibodies might afford protection if administered to infected animals. The administration of this antiserum was tested only at times late in the infection when it was felt that the toxaemia was pronounced. Treatment with ISAS, but not with BSAS, consistently protected animals against challenge.

The fact that this protection only increased the MTD without decreasing the numbers of organisms in the tissues is not surprising if it is assumed that the antisera did not contain antibodies against the micro-organisms; if such an assumption were correct, the toxin would continue to be produced and an animal would eventually succumb when the neutralising capacity of the serum was exhausted.

Earlier results however (table) had shown that treatment of infected mice with gentamicin was able to reduce the number of infecting organisms and perhaps, therefore, the source of toxin production. The data collected after treatment with a combination of the antibiotic and ISAS clearly supported this hypothesis in that approximately $40 \%$ of the animals receiving gentamicin plus ISAS were afforded "long-term survival" (fig. 4), i.e., survival for at least $96 \mathrm{~h}$.

The data presented in fig. 6 . show that administration of antiserum against heat-killed $P$. aeruginosa effectively reduced the numbers of micro-organisms in the tissues, presumably by the action of opsonising antibodies. In the liver this reduction was observed even within the relatively short interval $(4.5 \mathrm{~h})$ between treatment and the measurement of viable counts. On the other hand, similar treatment of infected mice with ISAS produced completely different results; the viable counts showed that ISAS did not lower the number of organisms in the infected tissues (fig. 5). In fact, the bacterial numbers recorded were greater than those seen previously in the same tissues and organs of untreated animals at death (table). These data indicate that the antibodies contained in the ISAS are not opsonising in nature and suggest that the significant increase in MTD observed in animals treated with the serum was due to antibodies directed against an extracellular toxin.

In conclusion, our data provide evidence for a diffusible lethal toxin 
produced by $P$. aeruginosa growing in the tissues of the host. In addition, our experimental model provides a means of testing in vivo the relevance of other bacterial products produced or demonstrated in vitro.

\section{SUMMARY}

Evidence is presented that a lethal toxin is produced by $P$. aeruginosa growing in the burned skin of experimental mice. After injection of approximately $100 P$. aeruginosa cells into the burned skin there was a rapid proliferation of organisms at the site of inoculation. When the organisms in the burned skin tissue reached a critical concentration, there was generalised toxaemia with subsequent mortality; the process was not reversible at this stage, even by reducing substantially the numbers of infecting organisms. However, when the reduction was accompanied by administration of rabbit serum prepared against filter-sterilised extracts of infected burned tissues, approximately $40 \%$ of the animals survived for at least $96 \mathrm{~h}$. The data suggests that the antiserum afforded protection by inactivating a toxin produced by the organisms growing in the infected burned tissues rather than by further reducing the numbers of infecting organisms.

\section{REFERENCES}

Alexander, J. W. 1971. Control of infection following burn injury. Archs Surg., Chicago, $103,435$.

Bartell, P. F., OrR, T. E. ANd Garcia, M. 1968. The lethal events in experimental Pseudomonas aeruginosa infection of mice. J. infect. Dis., 118, 165.

Callahan, L. T. 1974. Purification and characterization of Pseudomonas aeruginosa exotoxin. Infect. Immun., 9, 113.

Camprell, D. H., Garvey, J. S., Cremer, N. E. ANd Sussdorf, D. H. 1963. Methods in immunology: a laboratoty text for instruction and research, New York, p. 22.

Holder, I. A. AND JogAN, M. 1971. Enhanced survival in burned mice treated with antiserum prepared against normal and burned skin. J. Trauma, 11, 1041.

LIU, P. V. 1966. The roles of various fractions of Pseudomonas aeruginosa in its pathogenesis. III. Identity of the lethal toxins produced in vitro and in vivo. J. infect. Dis., 116, 481.

LIU, P. V. 1973. Exotoxins of Pseudomonas aeruginosa. I. Factors that influence the production of exotoxin A. J. infect. Dis., 128, 506.

LIU, P. V. AND HsIEH, H. 1973. Exotoxins of Pseudomonas aeruginosa. III. Characteristics of antitoxin A. J. infect. Dis., 128, 520.

LIU, P. V., YoshII, S. AND HsieH, H. 1973. Exotoxins of Pseudomonas aeruginosa. II. Concentration, purification and characterization of exotoxin A. J. infect. Dis., 128, 514.

MonCRIEF, J. A. AND TePlitz, C. 1964. Changing concepts in burn sepsis. J. Trauma, 4, 233.

Pavlovskis, O. R. 1972. Pseudomonas aeruginosa exotoxin: effect on cellular and mitochondrial respiration. J. infect. Dis., 126, 48.

Pavlovskis, O. R. ANd Gordon, F. B. 1972. Pseudomonas aeruginosa exotoxin: effect on cell cultures. J. infect. Dis., 125, 631.

Pavlovskis, O. R. AND Shackelford, A. H. 1974. Pseudomonas aeruginosa exotoxin in mice: localization and effect on protein synthesis. Infect. Immun., 9, 540.

Saymen, D. G., Nathan, P., Holder, I. A., Hill, E. O. and MacMillan, B. G. 1972. Infected surface wound: an experimental model and a method for the quantitation of bacteria in infected tissues. Appl. Microbiol., 23, 509.

Stieritz, D. D. AND Holder, I. A. 1975. Experimental studies of the pathogenesis of infections due to Pseudomonas aeruginosa: description of a burned mouse model. $J$. infect. Dis., 131, 688. 